\title{
Risk Factors Affecting Postoperative Morbidity in Laparoscopic Treatment of Perforated Appendicitis, a Single- Center Experience
}

\section{Perfore Apandisitlerin Laparoskopik Tedavisinde Morbidite Gelişimi Üzerine Etkili Risk Faktörleri, Tek Merkez Deneyimi}

\author{
Ahmet Surek ${ }^{\oplus}$, Mehmet Karabulut ${ }^{\oplus}$ \\ Department of General Surgery, Bakirkoy Dr. Sadi Konuk Training and Research Hospital, istanbul, Turkey
}

Received: 10.08.2020 / Accepted: 01.09.2020 / Published Online: 30.09.2020

Cite as: Surek A, Karabulut M. Risk factors affecting postoperative morbidity in laparoscopic treatment of perforated appendicitis, a single- center experience. Med J Bakirkoy 2020;16(3):272-9.

\begin{abstract}
Objective: Postoperative morbidity may occur more in laparoscopic treatment of perforated appendicitis than simple appendicitis. In this study, we aimed to investigate the risk factors affecting the development of morbidity in laparoscopic treatment of perforated appendicitis.

Method: The files of patients who underwent laparoscopic appendectomy due to perforated appendicitis were analysed retrospectively. Finding of perforation has been documented by surgeons who performed surgery. Information on the patients such as age, gender, Charlson Comorbidity Index (CCI), body mass index (BMI), ASA scores, symptom onset time, time between hospital admission and surgery, surgical findings, perforation sites, type of surgery, stump closure materials, white blood cell counts, pathology results and postoperative morbidities were recorded. Data were compared between patients with and without morbidity, and multivariate regression analysis of variables with significant $p$ value was performed.

Results: The rate of morbidity development in laparoscopic treatment of perforated appendicitis was $22.14 \%$ (66/298). In multivariate regression analysis, the onset of symptoms longer than 72 hours, proximal perforation, grade 5 diffuse peritonitis in surgical finding according to Disease Severity Score (DSS), conversion from laparoscopic to open surgery and gangrene or necrosis in histopathological finding were found to be effective risk factors in the development of morbidity. ( $p=0.013$, odds ratio $=1,455, p=0.010$, odds ratio $=2.009, p=0.002$, odds ratio $=2.648$, $p=0.014$, odds ratio $=6.537, p=0.003$, odds ratio $=1.843$; respectively).

Conclusion: The development of postoperative morbidity in laparoscopic treatment of perforated appendicitis is associated with late admission development of diffuse peritonitis, conversion to open surgery, proximal perforation and presence of necrosis. According to odds ratio, the risk factor with the highest probability of developing morbidity was found to be conversion to open surgery. We think that patients diagnosed with perforated appendicitis should be operated on as early as possible, routinely placing a drain should be avoided, and laparoscopic approach should be preferred as much as possible to reduce the morbidity rates.
\end{abstract}

Keywords: perforated appendicitis, laparoscopy, morbidity

öz

Amaç: Perfore apandisitlerin laparoskopik tedavisinde postoperatif morbidite basit apandisitlere göre daha fazla gelişmektedir. Biz bu çalışmada, perfore apandisitlerin laparoskopik tedavisinde morbidite gelişimine etki eden risk faktörlerini araştırmayı amaçladık.

Yöntem: Perfore apandisit nedeniyle laparoskopik apendektomi yapılan hastaların dosyaları retrospektif olarak incelendi. Perforasyon bulgusu ameliyatı yapan cerrahlar tarafından belgelenmiştir. Çalışmaya dahil edilen hastaların yaşı, cinsiyeti, Charlson Komorbidite Indeksi (CCI), vücut kitle indeksi (VKi) ASA skorları, semptom bașlangıç ve hastane bassvuru ile ameliyat arasında geçen süreleri, ameliyat bulguları, perforasyon yerleri, ameliyat şekilleri, güdük kapatma materyalleri, lökosit değerleri, patoloji sonuçları ve postoperatif morbiditeleri kayıt altına alındı. Veriler morbidite gelişsen ve gelişmeyen hastalarda karşılaştıııldı ve $p$ değeri anlamlı çıkan değişkenlerin multivariate regresyon analizi yapıldı.

Bulgular: Perfore apandisitlerin laparoskopik tedavisinde mobidite gelişme oranı \%22.14 (66/298) olarak izlenmiştir. Multivariate regresyon analizinde semptom başlangıcının üzerinden 72 saat geçmesi, ameliyat bulgularına göre perforasyon yerinin radiks olması, DSS'ye göre ameliyat bulgusunda grade 5 diffuz peritonit tablosu olması, laparoskopiden açığa dönülmesi ve post operatif histopatolojik bulguda gangren veya nekroz olması post operatif morbidite gelişimi üzerine etkili risk faktörleri olarak bulunmuştur $(p=0.013$, olasılık oranı $=1,455 ; p=0.010$, olasılık oranı $=2.009 ; p=0.002$, olasılık oranı $=2.648 ; p=0.014$, olasılık oranı=6.537; $p=0.003$, olasılık oranı=1.843; sirasıyla).

Sonuç: Perfore apandisitlerin laparoskopik tedavisinde post operatif morbidite geliş̧imi geç başvuru, diffüz peritonit gelişimi, açığa dönüş, radiks perforasyonu ve nekroz varlığı ile ilișkilidir. Olasılık oranlarına göre morbidite gelișme ihtimali en yüksek olan risk faktörü açığa dönüs olarak bulunmuştur. Apandisit perforasyonu tanısı alan hastaların olabildiğince erken ameliyat edilmesi, rutin dren yerleștirilmemesi ve morbidite gelişimini önlemek için mümkün olduğunca laparoskopik yaklaşım uygulanması gerektiğini düşünüyoruz.

Anahtar kelimeler: perfore apandisit, laparoskopi, morbidite

Corresponding Author:

ahmetsurek82@hotmail.com
A. Surek 0000-0002-5950-1067

M. Karabulut 0000-0002-1889-5637

(C) Telif hakkı Sağlık Bilimleri Üniversitesi Bakırköy Dr. Sadi Konuk Eğitim ve Araştırma Hastanesi'ne aittir. Logos Tıp Yayıncılık tarafindan yayınlanmaktadır. Bu dergide yayınlanan bütün makaleler Creative Commons Atff-GayriTicari 4.0 Uluslararası Lisansı ile lisanslanmıştır.

(c) Copyright Health Sciences University Bakırköy Sadi Konuk Training and Research Hospital. This journal published by Logos Medical Publishing.

Licenced by Creative Commons Attribution-NonCommercial 4.0 International (CC BY) 


\section{INTRODUCTION}

Acute appendicitis is the most common cause of sudden abdominal pain and emergency operations that require surgery, and is one of the most common abdominal surgical procedure performed by general surgeons ${ }^{(1)}$. Appendectomy is the gold standard in treatment ${ }^{(2)}$. Although acute appendicitis is usually treated successfully with early diagnosis and appropriate approach, perforation may occur in $16-39 \%$ of the cases, and may lead to life-threatening complications ${ }^{(3,4)}$. Perforated appendicitis have more morbidities and complications such as 3 times more frequent hospital stays, higher costs and 2.3 times greater number of fatalities than simple appendicitis ${ }^{(5,6)}$.

While open appendectomy was preferred for treatment in the 1990s, laparoscopic appendectomy became the gold standard in the 2000s (7,8). Laparoscopic appendectomy (LA) is an effective treatment method that can be applied safely in simple appendicitis treatment. The laparoscopic approach is superior to open appendectomy (OA) in terms of postoperative surgical site infections, analgesia requirement, average length of hospital stay, return to work, and overall recovery ${ }^{(9,10)}$. However, its role in complicated appendicitis is controversial due to more frequent intra-abdominal abscess development and longer operative times ${ }^{(11,12)}$. Despite the technical developments in LA, postoperative intraabdominal abscesses are bothersome for both surgeons and patients. In the laparoscopic approach, perforated appendicitis, obesity and young age are possible risk factors for the development of intraabdominal abscess after appendectomy ${ }^{(13,14)}$.

In this study, we aimed to determine the factors that may affect the development of postoperative morbidity in the laparoscopic treatment of perforated appendicitis.

\section{MATERIAL and METHODS}

The files of patients who underwent laparoscopic appendectomy between January 2017 and January 2020 were retrospectively reviewed. Patients older than 18 years of age and with the surgical finding of perforated appendicitis were included in the study. Patients younger than 18 years of age and who had no evidence of perforated appendicitis were excluded from the study. Information on the patients such as age, gender, Charlson Comorbidity Index (CCl), body mass index (BMI), American Society of Anesthesiologists (ASA) scores, onset of symptoms and time between hospital admission and surgery, surgical findings, perforation sites, surgery types, stump closure materials, leukocytes counts, pathology results and morbidities were recorded. Disease Severity Score (DSS) was used for classification according to the surgical findings ${ }^{(15)}$. According to the surgical findings, the patients were divided into 3 groups as perforated appendicitis with localized fluid (Grade 3), with regional abscess (Grade 4), and with diffuse peritonitis (Grade 5). Surgical site infection, prolonged ileus, and cardiopulmonary complications occurred within the first 30 days postoperatively were considered surgical morbidity. The parameters recorded in patients with and without morbidity were compared and the risk factors affecting the development of morbidity were determined by performing a multivariate risk analysis of the parameters that showed a significant difference in the $p$ value.

This study was carried out in accordance with the 1964 Helsinki Declaration and its recent amendments. Written consent was obtained from all participants. Permission was obtained from the local ethics committee (Ref. Nr:2020/274)

\section{Statistical Analysis}

SPSS (Statistical Package for the Social Sciences) 24. program (IBM, Armonk, NY) was used for statistical analysis. While evaluating the study data, descriptive statistical methods (average, standard deviation, median, frequency, ratio, minimum, maximum) as well as the Independent sample $t$ test for the comparisons of normally distributed parameters in two groups, and the Mann-Whitney $U$ test for the comparisons of two groups that did not show normal distribution were used The Pearson Chi-Square test was used for the analysis of qualitative data. Multivariate regression analysis of factors affecting the development of morbidity was performed. Significance was evaluated at $p<0.01$ and $p<0.05$ levels.

\section{RESULTS}

It was determined that a total of 1302 patients 
underwent laparoscopic appendectomy between January 2017 and January 2020. Of these patients, 298 (22.88\%) had signs of perforation. 197 (66.1\%) of the patients were male and 101 (33.9\%) of them were female. The mean age was 40.7. BMI was 27.3 $\mathrm{kg} / \mathrm{m}^{2}$. The mean Charlson comorbidity index score was 0.93 . The ASA score of $48(16.10 \%)$ patients was $3-4$. Mean symptom onset time was $2.53 \pm 1.14$ days. The mean time from hospital admission to surgery was determined as $10.16 \pm 4.16$ hours. Mean WBC countswere $16.5103 / \mu \mathrm{L}$.

When we examined the surgical findings, perforation of appendicitis was found in the distal appendix in 139 (46.64\%) and the proximal appendix in 159 (53.36\%) cases While 190 (53.69\%) patients had DSS grade 3 localized fluid, 38 (12.75\%) DSS grade 4 localized abscess and 70 (23.48\%) DSS grade 5 diffuse peritonitis. Conversion to open surgery required in $18(6.04 \%)$ patients. The reasons for conversion were determined as exploration difficulty due to adhesions and the revealing of the appendix radix as a result of appendix lysis. Partial cecum resection was performed in $21(7.04 \%)$ of the patients because the perforation was quite proximal and there was no distance to close the appendix stump. When we examined the stump closure materials, it was found that hemo-o-lok clips were used in 244 (81.87\%), endostapler (Ethicon flex $60 \mathrm{~mm}$ ) in $23(7.71 \%)$, and sutures in $31(10.40 \%)$ patients. It was determined that an abdominal drain was placed in only 245 (82.21\%) of 298 patients, (Table 1).

According to final histopathological evaluation, the patients had acute inflamed appendicitis $(n=67), 93$ phlegmonous appendicitis ( $n=93)$, gangrenous or necrotic appendicitis $(n=130)$, grade 1 neuroendocrine tumour $(n=3)$, mucinous neoplasia $(n=3)$, and mucocele $(n=2)$. In the lumen of the appendix of 67 patients, fecaloid was detected (Table 1).

Morbidity was observed in 66 (22.14\%) patients. Surgical site infection developed in $44(14.76 \%)$ of these patients. Of the patients who developed surgical site infection, superficial wound infection was observed in 8, deep wound infection in 4, and organ / space surgical site infection in 32 patients. Prolonged ileus developed in 16 patients and atelectasis in 6 patients. Diagnoses of patients with organ / space
Table 1. General and perioperative characteristics of patients.

\begin{tabular}{|c|c|}
\hline Mean age $\pm S D(\operatorname{Min} / \operatorname{Max})$ & $40.72 \pm 16.87(18-85)$ \\
\hline \multicolumn{2}{|l|}{ Gender, n (\%) } \\
\hline Female & $101(33.9 \%)$ \\
\hline Male & $197(66.1 \%)$ \\
\hline Mean BMI $\pm S D$ & $27.3 \pm 3.81 \mathrm{~kg} / \mathrm{m}^{2}$ \\
\hline $\begin{array}{l}\text { Mean Charlson comorbidity index } \pm \text { SD (Min/ } \\
\text { Max) }\end{array}$ & $\begin{array}{c}0.93 \pm 1.72 \\
(0-8)\end{array}$ \\
\hline \multicolumn{2}{|l|}{ ASA scores, $n$ (\%) } \\
\hline $1-2$ & $250(83.90 \%)$ \\
\hline 3-4 & $48(16.10 \%)$ \\
\hline Mean WBC & $16.510^{3} / \mathrm{uL}$ \\
\hline $\begin{array}{l}\text { Mean time interval between symptoms onset } \\
\text { and surgery (day) } \pm S D\end{array}$ & $2.53 \pm 1.14$ \\
\hline $\begin{array}{l}\text { Mean time interval hospital application and } \\
\text { surgery (hours) } \pm \text { SD (Min/Max) }\end{array}$ & $10.16 \pm 4.16(3-22)$ \\
\hline \multicolumn{2}{|l|}{$\begin{array}{l}\text { Intraoperative finding according to } \\
\text { Diasease Severity Score (DSS), } \mathrm{n}(\%)\end{array}$} \\
\hline Grade 3 perforated with localized free fluid & $190(53.69 \%)$ \\
\hline Grade 4 perforated with a regional abscess & $38(12.75 \%)$ \\
\hline Grade 5 perforated with diffuse peritonit & $70(23.43 \%)$ \\
\hline \multicolumn{2}{|l|}{ Site of perforation, $\mathrm{n}(\%)$} \\
\hline Proksimal(radix) & $159(53.35 \%)$ \\
\hline Distal (apex ve corpus) & $139(46.65 \%)$ \\
\hline \multicolumn{2}{|l|}{ Stump closure material, n (\%) } \\
\hline Endoclip & $244(81.88 \%)$ \\
\hline Suture & $31(10.40 \%)$ \\
\hline Endostapler & $23(7.72 \%)$ \\
\hline \multicolumn{2}{|l|}{ Abdominal drain, $\mathrm{n}(\%)$} \\
\hline Yes & $245(82.21 \%)$ \\
\hline No & $53(17.79 \%)$ \\
\hline Conversion to open surgery & $18(6.04 \%)$ \\
\hline Partial cecal resection & $21(7.04 \%)$ \\
\hline Mean operating time $(\min ) \pm S D(\operatorname{Min} / \operatorname{Max})$ & $82.25 \pm 28.08(24-190)$ \\
\hline \multicolumn{2}{|l|}{ Histopathological findings, $\mathrm{n}(\%)$} \\
\hline Acute inflamated & $67(22.48 \%)$ \\
\hline Phlegmonous & $93(31.20 \%)$ \\
\hline Gangrenous and necrosis & $130(43.62 \%)$ \\
\hline Mucosel & $2(0.67 \%)$ \\
\hline NET (Grade 1) & $3(1.00 \%)$ \\
\hline Mucinous neoplasm & $3(1.00 \%)$ \\
\hline \multicolumn{2}{|l|}{ Complications, n (\%) } \\
\hline \multicolumn{2}{|l|}{ Surgical site infection } \\
\hline superficial & $8(2.68 \%)$ \\
\hline deep & $4(1.34 \%)$ \\
\hline organ/space & $32(10.73 \%)$ \\
\hline Prolonged ileus & $16(5.36 \%)$ \\
\hline Atelectasis & $6(1.67 \%)$ \\
\hline Total morbidity & $66(22.14 \%)$ \\
\hline \multicolumn{2}{|l|}{ Clavien-Dindo classification, $\mathrm{n}$ (\%) } \\
\hline Grade 1 & $30(10.06 \%)$ \\
\hline Grade 2 & $18(6.04 \%)$ \\
\hline Grade 3 & $18(6.04 \%)$ \\
\hline 3a & $7(2.34 \%)$ \\
\hline $3 b$ & $11(3.69 \%)$ \\
\hline Re-operation & $11(3.69 \%)$ \\
\hline
\end{tabular}


Table 2. Comparison of patients characteristics and perioperative datas according to development of morbidity

\begin{tabular}{|c|c|c|c|}
\hline Variables & $\begin{array}{c}\text { Morbidity (-) } \\
(n=232)\end{array}$ & $\begin{array}{c}\text { Morbidity (+) } \\
n=66)\end{array}$ & $P$ value \\
\hline Mean age & $40,42 \pm 15,68$ & $41,82 \pm 20,63$ & ${ }^{\mathrm{b}} 0,553$ \\
\hline \multicolumn{4}{|l|}{ Gender } \\
\hline Female & 82 (35.3\%) & $19(28.8 \%)$ & ${ }^{\mathrm{a}} 0,321$ \\
\hline Male & $150(64.7 \%)$ & $47(71.2 \%)$ & \\
\hline Mean BMI & $27,01 \pm 3,74$ & $28,33 \pm 3,95$ & ' $0,013^{*}$ \\
\hline Mean CCl & $0,8 \pm 1,51$ & $1,39 \pm 2,27$ & ${ }^{c} 0,124$ \\
\hline \multicolumn{4}{|l|}{ ASA score } \\
\hline $1-2$ & $202(80.8 \%)$ & $48(19.2 \%)$ & ${ }^{\mathrm{a}} 0,002 * *$ \\
\hline 3-4 & $30(62.5 \%)$ & $18(37.5 \%)$ & \\
\hline Mean WBC & $16013,96 \pm 10565,12$ & $18420,61 \pm 25778,21$ & ${ }^{c} 0,907$ \\
\hline Mean time interval between symptoms onset and surgery(day) & $2,39 \pm 0,93$ & $3,05 \pm 1,46$ & ${ }^{\circ} 0,001 * *$ \\
\hline \multicolumn{4}{|l|}{ Time interval between symptoms onset and surgery } \\
\hline$<72 \mathrm{~h}$ & $135(58.18 \%)$ & $25(37.88 \%)$ & ${ }^{\circ} 0,001^{* *}$ \\
\hline$>72 \mathrm{~h}$ & $97(41.8 \%)$ & $41(62.12 \%)$ & \\
\hline Mean time interval hospital application and surgery(hour) & $10,06 \pm 4,25$ & $10,53 \pm 3,84$ & ${ }^{\mathrm{b}} 0,419$ \\
\hline \multicolumn{4}{|l|}{ Intraoperative finding according to Diasease Severity Score (DSS) } \\
\hline Grade 3 & $168(72.4 \%)$ & $22(33.3 \%)$ & ${ }^{\mathrm{a}} 0,001^{* *}$ \\
\hline Grade 4 & $25(10.8 \%)$ & $13(19.7 \%)$ & \\
\hline Grade 5 & $39(16.8 \%)$ & $31(47 \%)$ & \\
\hline \multicolumn{4}{|l|}{ Site of perforation } \\
\hline Proximal & $122(52.6 \%)$ & $17(25.75 \%)$ & ${ }^{\mathrm{a}} 0,001^{* *}$ \\
\hline Distal & $110(47.4 \%)$ & $49(74.25 \%)$ & \\
\hline \multicolumn{4}{|l|}{ Stump closure material } \\
\hline Endoclip & $201(86.6 \%)$ & $43(65.2 \%)$ & ${ }^{\mathrm{a}} 0,001 * *$ \\
\hline Suture & $16(6.9 \%)$ & $15(22.72 \%)$ & \\
\hline Endostapler & $15(6.5 \%)$ & $8(12.12 \%)$ & \\
\hline \multicolumn{4}{|l|}{ Abdominal drain } \\
\hline Yes & $184(79.3 \%)$ & $61(92.4 \%)$ & ${ }^{\mathrm{a}} 0,014 *$ \\
\hline No & $48(20.7 \%)$ & $5(7.6 \%)$ & \\
\hline Laparoscopically completed & 227 (81.1\%) & $53(18.9 \%)$ & ${ }^{\mathrm{a}} 0,001 * *$ \\
\hline Conversion to open surgery & $5(27.8 \%)$ & $13(72.8 \%)$ & \\
\hline \multicolumn{4}{|l|}{ Partial caecum resection } \\
\hline Yes & $217(93.5 \%)$ & $61(90.9 \%)$ & ${ }^{\mathrm{a}} 0,462$ \\
\hline No & $15(6.5 \%)$ & $5(9.1 \%)$ & \\
\hline Mean operating time & $78,37 \pm 25,81$ & $95,92 \pm 31,53$ & ${ }^{\mathrm{b}} 0,001 * *$ \\
\hline \multicolumn{4}{|l|}{ Histopathological findings } \\
\hline Acute inflamated & $51(21.98 \%)$ & $16(24.24 \%)$ & ${ }^{\mathrm{a}} 0,003 * *$ \\
\hline Phlegmanous & $83(35.77 \%)$ & $10(15.15 \%)$ & \\
\hline Gangrenoz and necrosis & $91(39.22 \%)$ & $39(59.09 \%)$ & \\
\hline \multicolumn{4}{|l|}{ Fecaloid } \\
\hline Yes & 185 (79.74\%) & $46(69.69 \%)$ & ${ }^{\mathrm{a}} 0,085$ \\
\hline No & 47 (20.76\%) & 20 (30.30\%) & \\
\hline
\end{tabular}

aPearson Chi-Square, ${ }^{b}$ Independent Sample t testi, ${ }^{c}$ Mann Whitney U Testi ${ }^{*} p<0,05,{ }^{* *} p<0,001$ 
Tablo 3. Multivariate regression analysis of variables that are significant in the morbidity.

\begin{tabular}{|c|c|c|c|c|}
\hline & \multirow[b]{2}{*}{ Multivariate $p$ value } & \multirow[b]{2}{*}{ Odd's Ratio } & \multicolumn{2}{|c|}{$95 \%$ C.I } \\
\hline & & & Lower & Upper \\
\hline ASA score 3-4 & 0.953 & 0.986 & 0.616 & 1.578 \\
\hline Conversion to open surgery & 0.014 & 6.537 & 1.470 & 29.065 \\
\hline Proximal perforation of appendicitis (radix) & 0.010 & 2.009 & 1.179 & 3.424 \\
\hline Stump closure material (suture) & 0.829 & 0.939 & 0.527 & 1.671 \\
\hline Abdominal drain & 0.183 & 2.006 & 0.720 & 5.593 \\
\hline DSS Grade 5 diffuse peritonitis & 0.002 & 2.648 & 1.216 & 3.986 \\
\hline Gangrenous or necrotic appendicitis & 0.003 & 1.843 & 1.223 & 2.777 \\
\hline Mean BMI & 0.135 & 1.070 & 0.979 & 1.169 \\
\hline Mean operating time & 0.060 & 1.012 & 1.000 & 1.024 \\
\hline Symptom onset (>72h) & 0.013 & 1.455 & 1.082 & 1.958 \\
\hline
\end{tabular}

surgical site infection were confirmed by computed tomography (CT) of the abdomen and intraabdominal abscess was observed in all 32 patients. The mean abscess size of these patients was $5.43 \pm 2.32 \mathrm{~cm}$. While 16 patients were treated with antibiotics only, drains were placed in 7 patients by interventional radiology, and 9 patients were re-operated. Antibiotic treatment was performed to patients with abscess of $<5 \mathrm{~cm}$. Interventional drainage was planned first for patients with $>5 \mathrm{~cm}$ abscess, but drainage could not be performed in 9 patients because the access was not suitable for placing the drain, and these patients were re-operated. Two patients with deep wound infection were operated due to evisceration, and a total of 11 patients underwent reoperation. According to Clavien Dindo classification, there were 30 patients who received only fluid therapy, electrolyte replacement and wound care in Grade 1, 18 patients received antibiotic treatment in Grade 2, and 18 patients underwent invasive drainage and reoperation in Grade 3. Grade 4 and 5 complications were not observed (Table 1). Mortality did not occur in any of our patients.

High BMI, higher ASA score, symptom onset time longer than 72 hours, conversion to open surgery, proximal perforation in appendicitis, use of sutures as stump closure material, DSS grade 5 diffuse peritonitis as surgical finding, insertion of a drain, presence of gangrenous or necrotic appendicitis as pathological findings and longer operative time were found to be significant as factors affecting the morbidity (Table 2).

When the multivariate regression analysis was perrformed, the symptom onset time longer than 72 hours, conversion to open surgery, proximal perforation of appendicitis, the DSS grade 5 diffuse peritonitis, gangrenous or necrotic appendicitis were found to be statistically significant factors effecting postoperative morbidity (Table 3 ).

\section{DISCUSSION}

Mortality and morbidity are higher in perforated appendicitis than in non-perforated appendicitis ${ }^{(16)}$. Studies have shown that perforated appendicitis is one of the most effective risk factors for the development of morbidity after appendectomy ${ }^{(17,18)}$. In a study, Frazee et al. reported total morbidity was $20 \%$ after surgery for perforated appendicitis and intraabdominal abscess was the most common cause of morbidity with an incidence of 11 percent ${ }^{(19)}$. Intraabdominal abscess is the most common complication after perforated appendicitis and occurs in 14-18\% of postoperative patients ${ }^{(20)}$. In the study by Guy et al., it was observed that intraabdominal abscess developed in $9 \%$ of the cases with perforated appendicitis after laparoscopic appendectomy ${ }^{(21)}$. In this study, postoperative morbidity developed in $22.14 \%$ $(66 / 298)$, and intraabdominal abscess in $10.93 \%$ $(32 / 298)$ of the cases with similar rates reported in the studies in the literature. However, in the literatu$r e$, it is unclear what factors caused such higher rates of morbidity development in perforated appendicitis after laparoscopy.

In a study, Asarias et al., reported that older age has an impact on the development of postoperative morbidity in perforated appendicitis and that the probability of intraabdominal abscess formation increased by $30 \%$ with each decade of life ${ }^{(22)}$. In the study of Ming 
et al., it was observed that infections developed more frequently on the postoperative wound site in males with complicated appendicitis ${ }^{(23)}$.

In a study, Guy et al. reported that gender and age are not effective in the development of morbidity ${ }^{(21)}$. In this study, we determined that gender and age have no effect on the development of morbidity. In a retrospective study of 2076 patients, increased morbidity development rates were observed after laparoscopic appendectomy in patients with an ASA score of 2 and above ${ }^{(18)}$. In this study, the morbidity rate was found to be higher in patients with ASA 3-4, but ASA 3-4 had not any significant effect on morbidity in the multivariate regression analysis.

In a cohort study of 4618 patients, diabetes mellitus was found to be effective in the development of intraabdominal abscess after laparoscopic appendectomy ${ }^{(17)}$. In the study of Cho et al., the comorbidity of the patients was found to be ineffective in the development of morbidity after laparoscopic appendectomy ${ }^{(24)}$. In this study, mean values of Charlson Comorbidity Indexes were found to be similar between both groups.

It has been found that BMI has no effect on postoperative morbidity in previous studies ${ }^{(17,18,24)}$. In our study, it was found that postoperative morbidity was significantly more frequently detected in overweight patients while it was found to be insignificant in multivariate analysis. The reason for the higher incidence of morbidity in patients with high BMI can be explained by the higher occurrence of wound site infections due to fat necrosis and thicker subcutaneous adipose tissue.

The time from the onset of symptoms to surgery is one of the important variables for the development of morbidity after laparoscopic appendectomies. In the study performed by Lasek et al., in comparisons made between 48 hours before and after surgery, intraabdominal abscess developed more frequently in patients who were operated after 48 hours (17). Similarly, in a study, Fair et al. found a higher rate of postoperative complications in appendectomies performed after 48 hours ${ }^{(25)}$. In this study, the duration of symptom onset of patients with morbidity was significantly longer than those without morbidity. In the multivariate analysis, interventions made 72 hours after the onset of symptoms were found to be an effective risk factor in the development of morbidity.

In the study of Dijk et al., it was concluded that operating patients up to 24 hours after hospital admission had no effect on postoperative morbidity ${ }^{(26)}$. In our study, all patients were operated within 24 hours after admission, and the time from hospital admission to surgery was similar in those with and without morbidity. It has been stated that preoperative CRP and $W B C$ values have no effect on the development of morbidity in the laparoscopic treatment of perforated appendicitis ${ }^{(21)}$. In our study, preoperative WBC values were similar between those who did, and didi not develop morbidity.

Although perforated appendicitis was determined as a risk factor for the development of morbidity after appendectomy, morbidity development rates were not compared according to the perforation sites. In this study, it was observed that postoperative complications developed more frequently in appendicitis perforated from the radix area compared to perforations from the distal appendix area such as the corpus and apex. In multivariate regression analysis, radix perforations were identified as an effective risk factor for morbidity after laparoscopic treatment in perforated appendicitis. In the study of Garst et al., it was stated that as the DSS scores increased, postoperative morbidity increased significantly after appendectomy ${ }^{(15)}$. In the study of Guy et al., It was observed that after laparoscopic treatment of perforated appendicitis, surgical findings according to DSS did not affect the development of morbidity ${ }^{(21)}$. In this study, the morbidity rates of patients who were grade 5 according to DSS, (cases with diffuse peritonitis), were found to be significantly higher than other grades, and in the multivariate regression analysis, it was found to be a risk factor affecting postoperative morbidity.

In the study of Lasek et al., it was stated that conversion to open surgery had no effect on postoperative morbidity ${ }^{(17)}$. In the study of Andert et al., postoperative morbidity was observed more frequently in conversion from laparoscopy and it was found to be a risk factor for the development of morbidity in multivariate analysis ${ }^{(27)}$. In this study, conversion was 
found to be a effective factor for morbidity, and in the multivariate analysis, and an effective risk factor in the development of postoperative morbidity. The reason for this can be explained by the fact that the majority of the cases of conversion from laparoscopy was DSS grade 5, the appendix was perforated from the radix, and superficial and deep facial wound infections due to the subumbilical midline incision were observed more frequently.

In the studies where stump closure materials were compared, no difference was found between use of endoloop, suture, endostapler, and endoclip in terms of postoperative morbidity and intra-abdominal abscess development ${ }^{(28-31)}$. In this study, although the postoperative morbidity rate was higher when the closure of the stump was performed with sutures, it was found to be insignificant as a risk factor on morbidity in multivariate analysis.

In a study, Castro et al. found no difference between patients with and without drains in terms of postoperative morbidity development in patients who had undergone laparoscopic treatment for perforated appendicitis (32). A recent Cochrane analysis found that placing drains in perforated appendicitis did not reduce the risk of morbidity, even increased 30-day morbidity with very little evidence ${ }^{(33)}$. In this study, postoperative morbidity was observed more frequently in patients with a drain, but placement of a drain was not found as a risk factor affecting morbidity in multivariate regression analysis.

In the study of Lasek et al. it was determined that the operation times were longer in patients who developed intra-abdominal abscess after laparoscopic appendectomy. ${ }^{(17)}$. In this study, operation time was significantly longer in patients who developed postoperative morbidity. In the multivariate regression analysis, it was found to be an insignificant factor.

In a study by Guy et al. it was bserved that histopathological findings after laparoscopic treatment of perforated appendicitis were not risk factors for the development of morbidity ${ }^{(21)}$. In this study, it was observed that morbidity rate was higher in patients with histopathological findings of gangrene or necrosis findings, and it was determined as a significant risk factor for the development of morbidity in mul- tivariate analysis. It was determined that the presence of fecaloid in the lumen did not increase morbidity.

This study has some limitations. Retrospective design of this study is the major limitation. Furthermore, this case series represented a complex, heterogeneous patient population dispersed over a significant period of time. However, as the study was conducted in a tertiary referral center, the high volume of patients underwent laparoscopy for perforated appendicitis so the results and the statistical analysis might be considered as reliable and valuable.

\section{CONCLUSION}

In this study, the onset of symptoms longer than 72 hours, proximal perforation, surgical finding of grade 5 diffuse peritonitis according to Disease Severity Score (DSS), conversion to open surgery, gangrene or necrosis in histopathological finding were found to be effective risk factors in the development of morbidity in multivariate regression analysis. Conversion to open surgery was found to be the variable with the highest risk factor for the development of morbidity according to odds ratio.. We think that patients diagnosed with perforated appendicitis should be operated on as early as possible, routine placiement of a drain should be avoided, and laparoscopic approach should be preferred as much as possible to reduce the morbidity rates.

Ethics Committee Approval: Bakirkoy Dr. Approval was obtained from the Clinical Research Ethics Committee of Sadi Konuk Training and Research Hospital (2020-13, 22.06.2020).

Conflict of Interest: The authors declare that they do not have any conflict of interest.

Funding: The authors declare that they have no competing financial interests

Informed Consent: Written consent was obtained from all participants.

\section{REFERENCES}

1. Sauerland S, Lefering R, Neugebauer EA. Laparoscopic versus open surgery for suspected appendicitis. Cochrane Database Syst Rev. 2002;(1):CD001546. https://doi.org/10.1002/14651858.CD001546

2. Cao J, Tao F, Xing $\mathrm{H}$, et al. Laparoscopic Procedure is Not Independently Associated With the Development of Intra- 
Abdominal Abscess After Appendectomy. Surg Laparosc Endosc Percutan Tech. 2017;27(5):409-14. https://doi.org/10.1097/SLE.0000000000000460

3. Al-Omran M, Mamdani M, McLeod RS. Epidemiologic features of acute appendicitis in Ontario, Canada. Can J Surg 2003;46(4):263-8. Available from: https://www.ncbi.nlm.nih. gov/pmc/articles/PMC3211626/

4. Fike FB, Mortellaro VE, Juang D, et al. The impact of postoperative abscess formation in perforated appendicitis. J Surg Res. 2011;170(1):24-6. https://doi.org/10.1016/j.jss.2011.03.038

5. Barrett $\mathrm{ML}$, Hines $\mathrm{AL}$, Andrews RM. Trends in Rates of Perforated Appendix, 2001-2010. Available from: https:// www.hcup-us.ahrq.gov/reports/statbriefs/sb159.pdf (cited 2018 April 1).

6. Andersson RE. Short and long-term mortality after appendectomy in Sweden 1987 to 2006. Influence of appendectomy diagnosis, sex, age, co-morbidity, surgical method, hospital volume, and time period. A national population-based cohort study. World J Surg. 2013;37(5):974-81. https://doi.org/10.1007/s00268-012-1856-x

7. Golub R, Siddiqui F, Pohl D. Laparoscopic versus open appendectomy: a meta-analysis. J Am Coll Surg. 1998;186(5):54553.

https://doi.org/10.1016/S1072-7515(98)00080-5

8. Andersson RE. Short-term complications and longterm morbidity of laparoscopic and open appendicectomy in a national cohort. Br J Surg. 2014;101(9):1135-42.

https://doi.org/10.1002/bjs.9552

9. Frazee RC, Roberts JW, Symmonds RE, et al. A prospective randomized trial comparing open versus laparoscopic appendectomy. Ann Surg. 1994;219(6):725-8; discussion 728-31. https://doi.org/10.1097/00000658-199406000-00017

10. Guller U, Hervey S, Purves $\mathrm{H}$, et al. Laparoscopic versus open appendectomy: outcomes comparison based on a large administrative database. Ann Surg. 2004;239(1):43-52. https://doi.org/10.1097/01.sla.0000103071.35986.c1

11. Sauerland S, Jaschinski T, Neugebauer EA. Laparoscopic versus open surgery for suspected appendicitis. Cochrane Database Syst Rev. 2010;(10):CD001546 https://doi.org/10.1002/14651858.CD001546.pub3

12. Gorter RR, Eker HH, Gorter-Stam MA, et al. Diagnosis and management of acute appendicitis. EAES consensus development conference 2015. Surg Endosc. 2016;30(11):4668-90. https://doi.org/10.1007/s00464-016-5245-7

13. Ming PC, Yan TY, Tat LH. Risk factors of postoperative infections in adults with complicated appendicitis. Surg Laparosc Endosc Percutan Tech. 2009;19(3):244-8. https://doi.org/10.1097/SLE.0b013e3181a4cda2

14. Luo CC, Chien WK, Huang CS, et al. National trends in therapeutic approaches and outcomes for pediatric appendicitis: aTaiwanese nationwide cohort study. Pediatr Surg Int. 2015;31(7):647-51. https://doi.org/10.1007/s00383-015-3718-8

15. Garst GC, Moore EE, Banerjee MN, et al. Acute appendicitis: a disease severity score for the acute care surgeon. J Trauma Acute Care Surg. 2013;74(1):32-6. https://doi.org/10.1097/TA.0b013e318278934a

16. Humes DJ, Simpson J. Acute appendicitis. BMJ. 2006; 333(7567):530-4. https://doi.org/10.1136/bmj.38940.664363.AE

17. Lasek A, Pędziwiatr M, Wysocki M, et al. Risk factors for intraabdominal abscess formation after laparoscopic appendectomy-results from the Pol-LA (Polish Laparoscopic Appendectomy) multicenter large cohort study. Wideochir Inne Tech Maloinwazyjne. 2019;14(1):70-8. https://doi.org/10.5114/wiitm.2018.77272

18. Tartaglia D, Fatucchi LM, Mazzoni A, et al. Risk factors for intra-abdominal abscess following laparoscopic appendectomy for acute appendicitis: a retrospective cohort study on
2076 patients. Updates Surg. 2020 Apr 27 https://doi.org/10.1007/s13304-020-00749-y

19. Frazee $R$, Abernathy $S$, Davis $M$, et al. Fast track pathway for perforated appendicitis. Am J Surg. 2017;213(4):739-41. https://doi.org/10.1016/j.amjsurg.2016.08.006

20. Beek MA, Jansen TS, Raats JW, et al. The utility of peritoneal drains in patients with perforated appendicitis. Springerplus. 2015;4:371. https://doi.org/10.1186/s40064-015-1154-9

21. Guy S, Wysocki P. Risk factors for intra-abdominal abscess post laparoscopic appendicectomy for gangrenous or perforated appendicitis: A retrospective cohort study. International Journal of Surgery Open. 2018;10:47-54.

https://doi.org/10.1016/j.ijso.2017.12.003

22. Asarias JR, Schlussel AT, Cafasso DE, et al. Incidence of postoperative intraabdominal abscesses in open versus laparoscopic appendectomies. Surg Endosc. 2011;25(8):2678-83. https://doi.org/10.1007/s00464-011-1628-y

23. Ming PC, Yee Yan TY, Tat LH. Risk factors of postoperative infections in adults with complicated appendicitis. Surg Laparosc Endosc Percutan Tech. 2009;19(3):244-8. https://doi.org/10.1097/SLE.0b013e3181a4cda2

24. Cho J, Park I, Lee D, Sung K, Baek J, Lee J. Risk factors for postoperative intra-abdominal abscess after laparoscopic appendectomy: analysis for consecutive 1,817 experiences. Dig Surg. 2015;32(5):375-81. https://doi.org/10.1159/000438707

25. Fair BA, Kubasiak JC, Janssen I, et al. The impact of operative timing on outcomes of appendicitis: a National Surgical Quality Improvement Project analysis. Am J Surg. 2015;209(3):498-502. https://doi.org/10.1016/j.amjsurg.2014.10.013

26. van Dijk ST, van Dijk AH, Dijkgraaf MG, Boermeester MA. Meta-analysis of in-hospital delay before surgery as a risk factor for complications in patients with acute appendicitis. Br J Surg. 2018;105(8):933-45. https://doi.org/10.1002/bjs.10873

27. Andert A, Alizai HP, Klink CD, et al. Risk factors for morbidity after appendectomy. Langenbecks Arch Surg. 2017;402(6):98793.

https://doi.org/10.1007/s00423-017-1608-3

28. Swank HA, van Rossem CC, van Geloven AAW, et al. Endostapler or endoloops for securing the appendiceal stump in laparoscopic appendectomy: a retrospective cohort study. Surg Endosc. 2014;28(2):576-83. https://doi.org/10.1007/s00464-013-3207-x

29. Al-Temimi MH, Berglin MA, Kim EG, et al. Endostapler versus Hem-O-Lok clip to secure the appendiceal stump and mesoappendix during laparoscopic appendectomy. Am J Surg. 2017;214(6):1143-8. https://doi.org/10.1016/j.amjsurg.2017.08.031

30. Mannu GS, Sudul MK, Bettencourt-Silva JH, et al. Closure methods of the appendix stump for complications during laparoscopic appendectomy. Cochrane Database Syst Rev. 2017;11(11):CD006437. https://doi.org/10.1002/14651858.CD006437.pub3

31. Ceresoli M, Tamini N, Gianotti L, et al. Are endoscopic loop ties safe even in complicated acute appendicitis? A systematic review and meta-analysis. Int J Surg. 2019;68:40-7. https://doi.org/10.1016/j.ijsu.2019.06.011

32. Aneiros Castro B, Cano I, García A, et al. Abdominal drainage after laparoscopic appendectomy in children: an endless controversy? Scand J Surg. 2018;107(3):197-200. https://doi.org/10.1177/1457496918766696

33. Li Z, Zhao L, Cheng Y, et al. Abdominal drainage to prevent intra-peritoneal abscess after open appendectomy for complicated appendicitis. Cochrane Database Syst Rev. 2018;5(5):CD010168. https://doi.org/10.1002/14651858.CD010168.pub3 